\title{
The Formation of AFTA and Trade Diversion: Evidence from China's Agricultural Exports*
}

\author{
NGUYEN KHANH DOANH $^{* *} \cdot$ JEEHOON LEE $^{* * *}$ AND YOON HEO ${ }^{* * * *}$
}

\begin{abstract}
This study analyzes the impacts of the formation of AFTA (ASEAN Free Trade Agreement) on China's agricultural exports. The Hausman-Taylor analysis is applied to panel data collected from China and its 68 trading partners from 1993-2012. Our major findings areas follows. First, the discrimination in tariffs imposed by AFTA diverts trade in agricultural products from China toward AFTA's member countries. Second, at the sectoral level, the trade diversion effects of AFTA's formation on China's exports are significant in the case of beverage and tobacco industries. AFTA and China need to focus more on diversifying and differentiating their farming products. To gain better access to AFTA's market, more investment in research and development activities is recommended as a cure for Chinese farmers. Moreover, this study implies that more efforts in reducing tariff and non-tariff barriers to further liberalize trade between China and AFTA could enhance their bilateral trade flows.
\end{abstract}

Keywords: AFTA, Gravity Model, Trade Creation, Trade Diversion, Hausman-Taylor

* An earlier version of this paper was presented at Sogang IIAS Research Series in December 2014.

** Associate Professor, Thai Nguyen University, Thainguyen, Vietnam; E-mail: nkdoanh@yahoo.com

*** Associate Professor, Sejong University, Seoul, Korea; E-mail: petra@sejong.ac.kr

**** Corresponding author, Professor, Sogang University, Seoul, Korea;

E-mail: hury@sogang.ac.kr

DOI: $10.16934 /$ isr.17.1.201606.25 


\section{INTRODUCTION}

The impacts of a trade bloc's formation on trade flows have long been a controversial issue. Some scholars view a regional trade agreement (RTA) as a stepping stone toward global integration since improved trade performance among members of an RTA acts as an impetus for expanding trade to the rest of the world (Ethier 1998). However, scholars on the opposite side hold the view that because of the reduction of tariffs among members, an RTA discriminates against nonmember countries, which hinders deeper economic integration on a global scale (Bhagwati 1995; Krueger 1997). Whether an RTA creates or diverts trade remains an ongoing debate both theoretically and empirically (Koo et al. 2006; Fox et al. 2008).

The past decades have also witnessed an intensive growth in bilateral trade flows between ASEAN countries and China. China has constantly maintained the position of being a large trading partner of ASEAN and vice versa; and the Southeast Asian countries have continuously expanded their export markets in China. The Framework Agreement on Comprehensive Economic Cooperation signed in 2002 between ASEAN and China was to further strengthen the trade relationship between the two sides.

One of the issues that stakeholders are concerned with is whether or not the formation of the ASEAN Free Trade Agreement (AFTA)in 1992 burdens the longterm trade relationship between the two partners when the Common Effective Preferential Tariff (CEPT) was applied within AFTA; the latter had set up a scheme for removing tariffs among ASEAN economies. This study attempts to scrutinize the trade diversion effects of AFTA on China, taking agricultural exports as a case study.

China is one of the largest partners of AFTA countries in the trading of farming products. China's main exports include vegetables, fruits, fishery products, and tobacco, whereas its major imports from AFTA include rubber, vegetable oils and fats, vegetables, and fruits. According to data collected from UN Comtrade, there are some points that should be taken into account in the trading of agricultural products between the two. Since CEPT came into effect in 1993, the annual growth rate of AFTA's imports from China declined dramatically, from $35 \%$ to $8.9 \%$ within the periods 1988-1992 and 1993-2012, respectively. China used to be a large exporter of farming products to AFTA, accounting for $10.49 \%$ of the market in 1988. However, its market share followed a steady downward trend, ending at $7.67 \%$ in 2012. China had a low complementarity index $^{1}$ in agriculture with AFTA (a value of about 0.02 in 2012), which indicates that China's agricultural export structure is not complementary to AFTA's agricultural import structure.

This study investigates the effects of AFTA on China's agricultural exports. 
To do that, we first review theoretical and empirical issues on the effects of a trade bloc's formation on a nonmember country. Based on the estimated empirical results, we will provide the policy implications of our findings.

Unlike other studies analyzing the effects of AFTA on trade with time series or cross-sectional data, this study provides comprehensive insights into the effects of AFTA with panel data over a period of 20 years from 1993-2012. The use of panel data allows for individual heterogeneity (Baltagi 2005) and brings about more efficient outputs. Moreover, although there has been some empirical evidence of the effects of a preferential trade agreement from the perspective of member countries, there appears to be a lack of evidence from nonmember economies. Hence, this study attempts to address this issue by contributing empirical findings from the case of AFTA and one nonmember partner, namely China. Furthermore, to incorporate the advantages and overcome the shortcomings of both the fixed and random effects models, which have been widely used in many studies, we employ a Hausman-Taylor analysis for the panel data.

\section{EMPIRICAL ANALYSIS}

\section{Theoretical Framework}

The relationship between a regional trade agreement (RTA) and bilateral trade performance has remained a controversial issue over the past decades. Viner (1950) pioneered studies on the effects of a trade bloc by introducing trade creation and diversion effects. At one extreme, trade creation appears when high cost domestic products from one bloc's member country are replaced by low cost products that are imported from another bloc's member country. At the other extreme, trade diversion exists when low cost products from the rest of the world are replaced by high cost ones from member countries resulting from the reduction in import tariffs among the trade bloc's members.

Following Viner, extensive literature has tried to explain the effects of a regional trade agreement (de Paz et al. 1999; Frankel et al. 1998; Levy 1997). A regional trade agreement can be considered as a "building bloc" that stimulates global economic integration (Ethier 1998). On the contrary, an RTA can be blamed for trade discrimination between member and nonmember countries, which restricts further multilateralism (Bhagwati 1995; Krueger 1997). Theoretically, whether an RTA is creating or diverting trade remains an ongoing debate.

So far, there has been a growing body of empirical evidence on the effects of a regional agreement on trade. Regional trade agreements tend to stimulate trade flows when tariff rates within the bloc are reduced (Susanto et al. 2007; Hassan 2001; Clausing 2010). In some cases, the growth in trade flows among participants may boost their overall income, which in turn increases their demands for imports from outside countries (Koo et al. 2006). In contrast, a variety of studies has 
pointed out trade blocs' diversion effects. Romalis (2007) reported that tariff discrimination imposed by members of NAFTA was associated with a decline in their imports from the rest of the world. Jugurnath et al. (2007) discovered the trade diversion effects of RTAs in the cases of APEC, MERCOSUR, and NAFTA.

Generally, a reduction in trade barriers among participants of a regional trade agreement is associated with discrimination between member and nonmember economies. To date, there has been no consensus reached among economists, both theoretically and empirically, as to whether a regional trade agreement facilitates or restricts trade flows. Therefore, trade creation and diversion effects can only be determined on a case by case basis.

\section{Model}

\section{(1) Methodology}

We employ a modified gravity model in order to analyze the effects of AFTA on China's agricultural exports. Based on the idea that bilateral trade flows among countries depend on their economic sizes and geo-graphical distances, the gravity model has been widely used in empirical studies on international trade (Medvedev 2010; Ekanayake et al. 2010). The gravity model used in this study has the following specification:

$$
\begin{aligned}
\ln E X_{i j t}= & \beta_{0}+\beta_{1} \ln G D P_{i t}+\beta_{2} \ln G D P_{j t}+\beta_{3} \ln P O P_{i t}+\beta_{4} \ln P O P_{j t} \\
& +\beta_{5} \ln D I S T_{i j}+\beta_{6} \ln G D P P C_{-} D I F_{i j t}+\beta_{7} A D J_{i j}+\beta_{8} L A N G_{i j} \\
& +\beta_{9} C O L_{i j}+\beta_{10} A F T A+e_{i j t}
\end{aligned}
$$

where, at time $\mathrm{t}$,

EX $_{\mathrm{ijt}}$ is China (country i)'s agricultural exports to country $\mathrm{j}$,

GDP $_{\text {it }}$ is China's Gross Domestic Product (GDP),

$\mathrm{GDP}_{\mathrm{jt}}$ is country j's GDP,

$\mathrm{POP}_{\text {it }}$ is China's population,

$\mathrm{POP}_{\mathrm{jt}}$ is country $\mathrm{j}$ 's population,

GDPPC_DIF $F_{\mathrm{ijt}}$ is the difference in per capita GDP between China and country $\mathrm{j}$. Additionally,

DIST $_{i j}$ is the geographical distance from China's capital to that of country $j$, $A D J_{i j}$ is a dummy variable that takes the value of 1 if China and country $j$ share a common border, and 0 otherwise,

$\mathrm{LANG}_{\mathrm{ij}}$ is a dummy variable taking a value of 1 if China and country $\mathrm{j}$ share a common language, and 0 otherwise,

COL is a dummy variable taking a value of 1 if China and country $j$ have a colonial relation, and 0 otherwise, 
AFTA is a dummy variable taking a value of 1 if country $j$ is an AFTA member, and 0 otherwise, and

$\mathrm{e}_{\mathrm{ijt}}$ is an error term.

Trade is considered to be positively related to economic size, which is instrumented by GDP. The GDP of an exporting country reflects its capacity to export, while the GDP of importing country reflects its demand for imports (Frankel 1993). Hence, the coefficients on GDP for both China and its trading partners are expected to be positive.

Population can be either a curse or a blessing on trade. At one extreme, a country with a large population could diversify its products to meet domestic demand; therefore, its imports will decline, indicating a negative impact of population on trade (Falvey et al. 2009). At the other extreme, a country with a large population could effectively promote a division of labor, which is known as the economies of scale effect (Oguledo and MacPhee 1994). Therefore, its imports will increase, indicating a positive impact of population on trade.

Geographical distances between countries burden bilateral trade flows because greater distances generate higher transport and information costs, where the latter are charged against trading partners (Sohn 2005). Therefore, $\beta_{5}$ is expected to have a negative sign.

The differences in per capita GDP between China and its trading partners are added to the model to capture the Linder hypothesis, which states that bilateral trade flows tend to be larger between trading partners with a high level of similarity in per capita income (Tang 2003). A negative sign on GDPPC_DIF ijt $_{\text {s }}$ supports the Linder hypothesis. Otherwise, a positive coefficient reflects the Heckscher-Ohlin hypothesis on factor endowment (Ekanayake et al. 2010).

Adjacency, a common language, and common colonial relationships are factors that contribute to a high volume of trade (Clarete et al. 2003). Consequently, $\beta_{7}, \beta_{8}$, and $\beta_{9}$ are expected to be positive.

AFTA can either create or divert trade from China. If $\beta_{10}$ is positive, it means that AFTA's formation is associated with an enhancement in China's agricultural exports. Otherwise, $\beta_{10}$ will be negative if AFTA induces member economies to import agricultural products from sources within the bloc other than China.

To estimate a gravity model, the fixed and random effects models have been widely used. The fixed effects model allows for country-pair heterogeneity giving each country-pair its own intercept. In addition, the model can reduce potential specification errors caused from omitting important variables. One shortcoming of this model, however, is that time-invariant variables are eliminated.

Unlike the fixed effects model, the random effects model incorporates the differences between cross-sectional entities by allowing the intercept to change; however, the amount of change is random. The advantage of the random effects model is that it uses both time-series and cross-sectional variations. However, the 
model assumes that there is no correlation between all the regressors and individual effects.

To incorporate the advantages of both the fixed and random effects models, and to overcome their shortcomings, Hausman and Taylor (1981) introduced a new approach in which both time-variant and time-invariant effects are included into the model. Therefore, in this study, we apply the Hausman-Taylor model.

The Hausman-Taylor model is proposed as follows:

$$
y_{i t}=\beta_{1} x_{1 i t}+\beta_{2} x_{2 i t}+\delta_{1} z_{1 i}+\delta_{2} z_{2 i}+\mu_{i}+\varepsilon_{i t}
$$

where i denotes subgroup $I=1, \ldots, n$ and $\mathrm{t}$ denotes time.

Here, $\mathrm{x}_{1 \mathrm{it}}$ and $\mathrm{x}_{2 \mathrm{it}}$ are time-varying while $\mathrm{z}_{1 \mathrm{i}}$ and $\mathrm{z}_{2 \mathrm{i}}$ are time-invariant. The model assumes that $\mathrm{x}_{1 \mathrm{it}}$ and $\mathrm{z}_{1 \mathrm{i}}$ are uncorrelated with $\mu_{\mathrm{i}}$ and $\varepsilon_{\mathrm{it}} ; \mathrm{X}_{2 \mathrm{it}}$ and $\mathrm{Z}_{2 \mathrm{i}}$ are correlated with $\mu_{\mathrm{i}}$ but not $\varepsilon_{\mathrm{it}}$. Temporal means that $\overline{y_{i}}, \overline{x_{i}}$, and $\overline{\varepsilon_{i}}$ are created by the time-averaging dependent and explanatory variables, and $\varepsilon_{\mathrm{it}}$. Thus, model (2) becomes:

$$
y_{i t}-\overline{y_{i}}=\beta_{1}\left(x_{1 i t}-\overline{x_{1 i}}\right)+\beta_{2}\left(x_{2 i t}-\overline{x_{2 i}}\right)+\left(\varepsilon_{i t}-\overline{\varepsilon_{i}}\right),
$$

where $x_{1 i t}-\overline{x_{1 i}}$ and $x_{2 i t}-\overline{x_{2 i}}$ are used as instruments to estimate $\beta_{1}$ and $\beta_{2}$. By employing a series of instrumental variables regression, the Hausman-Taylor estimates in (2) are obtained.

\section{(2) Data Sources}

The annual data on China and its 68 trading partners used in this study span the period 1993-2012. According to the World Trade Organization's classification, agricultural products are defined to incorporate SITC0, SITC1, SITC2 (minus 28, 29), and SITC4. Agricultural export data are obtained from the UN Comtrade. Data on GDP, per capita GDP as reported in millions of USD, and population as measured in millions of people come from the IMF's World Economic Outlook Database. Data on distance are extracted from the website vi.thetimenow.com. Data on language, adjacency, and colonial relationships are collected from the Economist Intelligence Unit.

\section{ESTIMATED RESULTS}

In order to investigate the effects of AFTA on China's agricultural exports, the study employs a Hausman-Taylor analysis at both the aggregate and 1-digit sectoral levels. The estimates for the gravity model at the aggregate level are reported in Table 1. 
TABLE 1. THE EFFECTS OF AFTA ON CHINA's AgRiCULTURAL EXPORTS AT THE AGGREGATE LEVEL

\begin{tabular}{lccc}
\hline \multicolumn{1}{c}{ Variables } & Coefficient & Z-test & Probability \\
\hline CONST & $22.067^{* *}$ & 2.12 & 0.034 \\
\hline $\operatorname{lnGDP}_{\mathrm{it}}$ & $0.88^{* * *}$ & 10.57 & 0.000 \\
\hline $\operatorname{lnGDP}_{\mathrm{jt}}$ & $0.69^{* * *}$ & 9.49 & 0.000 \\
\hline $\operatorname{lnPOP}_{\mathrm{it}}$ & $-3.03^{*}$ & -1.93 & 0.054 \\
\hline $\operatorname{lnPOP}_{\mathrm{jt}}$ & $0.24^{* *}$ & 2.46 & 0.014 \\
\hline $\operatorname{lnDIST}_{\mathrm{ij}}$ & $-1.13^{* * *}$ & -4.57 & 0.000 \\
\hline $\operatorname{lnPGDP}_{-} \mathrm{DIF}_{\mathrm{ijt}}$ & $-0.15^{* * *}$ & -4.00 & 0.000 \\
\hline ADJ & -0.24 & -0.55 & 0.583 \\
\hline LANG & $2.40^{* * *}$ & 4.34 & 0.000 \\
\hline COL & 0.36 & 0.65 & 0.513 \\
\hline AFTA & $-0.67^{* * *}$ & -3.51 & 0.000 \\
\hline Wald Chi ${ }^{2}(10)$ & & 2681.95 & 0.000 \\
\hline
\end{tabular}

SOURCE: The authors' computation.

NOTE: ${ }^{*},{ }^{* *}$, and ${ }^{* * *}$ indicate significance at the $0.1,0.05$, and 0.01 levels respectively.

The GDP coefficients for both countries are positive and significant at the $1 \%$ level; this confirms the positive correlation between economic size and trade flows. The coefficient on population is negative and significant at the $10 \%$ level. In contrast, the coefficient on the trading partners' population is positive and significant; this shows that a $1 \%$ growth in the trading partner's population contributes to a $0.24 \%$ increase in China's agricultural exports.

Distance is proven to be a barrier to trade since its coefficient is negative and significant at the $1 \%$ level. The coefficient on the difference in per capita GDP between two countries is negative and significant. This negative sign indicates that China's pattern of agricultural exports reflects Linder's hypothesis. The coefficients on language and colonial relationships have their expected signs, which suggest the positive effects of these cultural and historical characteristics on trade. The coefficient on adjacency is negative but insignificant.

The dummy variable on AFTA captures the effects of this trade bloc on China's agricultural exports. The coefficient of AFTA is negative and significant, confirming that the formation of AFTA diverts trade from China to its member economies. In fact, China's share in ASEAN's agricultural imports is relatively small (around 8\% in 2012), whereas ASEAN's member economies are their major source of agricultural imports (around $29 \%$ in 2012). ${ }^{2}$ Moreover, the agricultural export structures of China and ASEAN countries are competitive rather than complementary. Therefore, tariff reduction after the formation of AFTA might serve as a significant factor to further strengthen the long-term and firm-trade relationships among the member nations; this diverts trade from a nonmember partner such as China. 
TABLE 2. THE EFFECTS OF AFTA ON CHINA's AGRICULTURAL EXPORTS AT THE 1-Digit SECTORAL LEVEL

\begin{tabular}{|c|c|c|c|c|}
\hline Variables & $\begin{array}{l}\text { 0. Food and live } \\
\text { animals }\end{array}$ & $\begin{array}{l}\text { 1. Beverages and } \\
\text { tobacco }\end{array}$ & $\begin{array}{l}\text { 2. Crude } \\
\text { materials }\end{array}$ & $\begin{array}{l}\text { 3. Animal, vegetable } \\
\text { oil, fats }\end{array}$ \\
\hline CONST & $\begin{array}{c}20.82^{*} \\
(1.77)\end{array}$ & $\begin{array}{r}3.60 \\
(0.15)\end{array}$ & $\begin{array}{r}13.00 \\
(0.89)\end{array}$ & $\begin{array}{c}160.31^{* * *} \\
(6.54)\end{array}$ \\
\hline $\operatorname{lnGDP}_{\text {it }}$ & $\begin{array}{l}0.95^{* * *} \\
(9.97)\end{array}$ & $\begin{array}{l}0.39^{* *} \\
(2.13)\end{array}$ & $\begin{array}{l}0.80^{\text {*** }} \\
(6.95)\end{array}$ & $\begin{array}{l}1.79^{* * *} \\
(9.44)\end{array}$ \\
\hline $\operatorname{lnGDP}_{\mathrm{jt}}$ & $\begin{array}{l}0.68^{* * * *} \\
(8.03)\end{array}$ & $\begin{array}{r}0.25 \\
(1.39)\end{array}$ & $\begin{array}{l}0.94^{* * *} \\
(9.77)\end{array}$ & $\begin{array}{l}0.60^{\text {**** }} \\
(3.17)\end{array}$ \\
\hline $\operatorname{lnPOP}{ }_{\text {it }}$ & $\begin{array}{r}-3.26^{*} \\
(-1.83)\end{array}$ & $\begin{array}{r}0.58 \\
(0.17)\end{array}$ & $\begin{array}{r}-2.88 \\
(-1.30)\end{array}$ & $\begin{array}{l}-25.29^{* * *} \\
(-7.24)\end{array}$ \\
\hline $\operatorname{lnPOP}_{\mathrm{jt}}$ & $\begin{array}{r}0.22^{*} \\
(1.88) \\
\end{array}$ & $\begin{array}{l}1.11^{* * * *} \\
(3.59) \\
\end{array}$ & $\begin{array}{l}0.33^{* * * *} \\
(2.76) \\
\end{array}$ & $\begin{array}{l}1.18^{* * * *} \\
(3.56) \\
\end{array}$ \\
\hline $\operatorname{lnDIST}_{\mathrm{ij}}$ & $\begin{array}{l}-0.97^{* * *} \\
(-3.21)\end{array}$ & $\begin{array}{r}-1.52 \\
(-1.55)\end{array}$ & $\begin{array}{l}-0.85^{* * * 6} \\
(-3.37)\end{array}$ & $\begin{array}{r}-1.21 \\
(-1.15)\end{array}$ \\
\hline lnPGDP_DIF ${ }_{\mathrm{ijt}}$ & $\begin{array}{l}-0.12^{* * *} \\
(-2.79)\end{array}$ & $\begin{array}{r}0.07 \\
(0.89)\end{array}$ & $\begin{array}{r}0.02 \\
(0.31)\end{array}$ & $\begin{array}{r}0.00 \\
(0.00)\end{array}$ \\
\hline ADJ & $\begin{array}{r}-0.36 \\
(-0.68)\end{array}$ & $\begin{array}{r}-1.25 \\
(-0.73)\end{array}$ & $\begin{array}{r}-0.23 \\
(-0.50)\end{array}$ & $\begin{array}{r}-1.65 \\
(-0.89)\end{array}$ \\
\hline LANG & $\begin{array}{l}2.46^{* * *} \\
(3.64)\end{array}$ & $\begin{array}{c}4.56^{* *} \\
(2.06)\end{array}$ & $\begin{array}{l}1.79^{* * *} \\
(3.19)\end{array}$ & $\begin{array}{l}5.33^{* *} \\
(2.28)\end{array}$ \\
\hline $\mathrm{COL}$ & $\begin{array}{r}0.70 \\
(1.03)\end{array}$ & $\begin{array}{r}0.44 \\
(0.20)\end{array}$ & $\begin{array}{r}-0.01 \\
(-0.01)\end{array}$ & $\begin{array}{r}0.38 \\
(0.16)\end{array}$ \\
\hline AFTA & $\begin{array}{r}-0.24 \\
(-1.12)\end{array}$ & $\begin{array}{l}-1.22^{* * * *} \\
(-2.86)\end{array}$ & $\begin{array}{r}0.14 \\
(0.56)\end{array}$ & $\begin{array}{r}-0.67 \\
(-1.09)\end{array}$ \\
\hline
\end{tabular}

SOURCE: The author's computation.

NOTE: The values in the parentheses denotes the z-statistics; ${ }^{*},{ }^{* *}$, and ${ }^{* * *}$ indicate significance at the $0.1,0.05$, and 0.01 levels respectively.

Table 2 presents results for the Hausman-Taylor regressions across the four different agriculture sectors (dividing by 1-digit SITC). Conventional variables (including GDP, population, distance, and language) behave the same as the aggregate level. The coefficient of the difference in per capita GDP is positive and insignificant in the categories of beverages and tobacco; crude materials; and animal, vegetable oil, and fats; however, it is negative and significant in food and live animals. The latter suggests that China's pattern of exports in this sector captures Linder's theory. The coefficients on colonial relationships and adjacency are insignificant across the four sectors.

At the sectoral level, the coefficient on AFTA is negative in the cases of food and live animals; beverages and tobacco; animal, vegetable oil, and fats, while positive in the case of crude materials. However, this coefficient is significant in the case of beverages and tobacco, and insignificant in others. Therefore, AFTA's formation exerts trade diversion effects on beverages and tobacco, and ambiguous effects on the remaining 1-digit agricultural sectors.

The findings of this study are contrary to the findings of MacPhee and Sattayanuwat (2014), which stated that AFTA's formation does not divert its members' imports from outside the countries. However, MacPhee and Sattayanuwat 
(2014) only considered the effect on total trade. The impacts of AFTA on specific industries, especially agriculture, have not been taken into account, which explains the contradictory results. Again, this study's findings are also different from what has been found in Koo et al. (2006), which pointed out that AFTA does not divert trade in agricultural products. The difference can be explained by the fact that Koo et al. (2006) investigated the effect on trade in agriculture for all AFTA's nonmember countries. As mentioned in that study, AFTA's structure of agricultural trade with nonmember partners is complementary. However, in this study, when examining the case of agricultural trade with China separately, we have pointed out that the structure of the agricultural trade between the two sides is competitive, not complementary.

\section{CONCLUSION}

The removal of trade barriers among participants under a regional trade agreement is associated with discrimination between member and nonmember economies. To date, there has been an ongoing debate as to whether a regional trade agreement facilitates or hinders trade flows among trading partners, theoretically and empirically. This study attempts to search for the effects of AFTA's formation on trade flows of nonmember economies, taking China's agricultural exports as a case study. The Hausman-Taylor analysis is applied to annual data collected from China and its 68 trading partners. The following issues have been addressed by the study.

Firstly, at the aggregate level, the coefficient on AFTA is negative and significant. This result suggests that the exports of agricultural products are diverted from China as a result of the removal of trade barriers within AFTA's member economies.

Secondly, to further investigate the effects of AFTA on China's agricultural exports, the study also performs Hausman-Taylor regressions at the 1-digit sectoral level. The coefficient on AFTA is negative and significant in beverages and tobacco, and insignificant in the three remaining 1-digit agricultural sectors. We conclude that AFTA's formation generates trade diversion effects on beverages and tobacco, and ambiguous effects on the three other sectors.

The study's findings once again confirm that the effects of a regional trade agreement can only be judged on a case by case basis. Because the complementarity index of China's agricultural products to AFTA is low, the case of AFTA and China suggests that the country should focus on diversifying and differentiating its farming products in order to avoid fierce competition from members with preferential treatment, and to gain better access to AFTA's market. More investment in research and development activities to improve the quality of farming products is, therefore, recommended as a cure. Moreover, the findings of this study imply that more efforts in reducing tariff and non-tariff barriers to further liberalize trade 
between China and AFTA's economies should be accelerated so as to enhance their bilateral trade flows. In fact, the agreement on trade in goods between the two sides has been implemented since 2005. It is expected that the agreement will play an active role in boosting trade between China and AFTA.

This study has sought to ascertain the trade diversion effects of AFTA on China's agricultural exports. In other words, the loss to China's farming product exporters has been confirmed. However, the magnitude of the loss and sector that suffered the most has not been identified. Therefore, further studies on this issue should be undertaken so that a strategic plan can be outlined to tackle the impacts posed by AFTA's formation.

\section{REFERENCES}

Baltagi, Badi H. 2005. Econometric Analysis of Panel Data 3rd Ed. New York: John Wiley and Sons.

Bhagwati, Jagdish. 1995. "U.S. Trade Policy: The Infatuation with Free Trade Areas." In The Dangerous Drift to Preferential Trade Agreements edited by Jagdish Bhagwati and Anne O. Krueger, Washington, D.C: American Enterprise Institute: $1-18$.

Clarete, Ramon L., Christopher Edmonds, and Jessica S. Wallack. 2003. "Asia Regionalism and Its Effects on Trade in the 1980s and 1990s." Journal of Asian Economics 14(1): 91-129.

Clausing, Kimberly A. 2010. "Trade Creation and Trade Diversion in the CanadaUnited States Free Trade Agreement." The Canadian Journal of Economics 34(3): 677-696.

de Paz, Elena Sanchez, Jose Antonio Novo Peteiro, and Jose Mendez Naya. 1999. "Endogenous Preferential Trade Agreements." Journal of Economic Integration 14(3): 419-431.

Ekanayake, E. M., Amit Mukherjee, and Bala Veeramacheneni. 2010. "Trade Blocks and the Gravity Model: A Study of Economic Integration among Asian Developing Countries." Journal of Economic Integration 25(4): 627-643.

Ethier, Wilfred J. 1998. "The New Regionalism." Economic Journal 108(449): 1149-1161.

Falvey, Rood, Neil Foster, and David Greenaway. 2009. "Trade, Imitative Ability and Intellectual Property Rights." Review of World Economics 145: 373-404.

Fox, Alan K., William Powers, and Ashley Winston. 2008. "Textile and Apparel Barriers and Rules of Origin: What's Left to Gain after the Agreement on Textiles and Clothing?" Journal of Economic Integration 2(3): 656-684.

Frankel, Jeffrey A. 1993. "Is Japan Creating a Yen Bloc in East Asia and the Pacific?" In Regionalism and Rivalry: Japan and the United States in Pacific Asia edited by Jeffrey A. Frankel and Miles Kahler. Chicago: University of Chicago 
Press.

Frankel, Jeffrey A., Ernesto Stein, and Shang-Jin Wei. 1998. "Continental Trading Blocs: Are They Natural or Supernatural?" In The Regionalization of the World Economy edited by Jeffrey Frankel, Chicago: University of Chicago Press, 91-120.

Jugurnath, Bhavish, Mark Stewart, and Robert Brooks. 2007. "Asia/Pacific Regional Trade Agreements: An Empirical Study." Journal of Asian Economics 18: 974-987.

Hassan, Kabir M. 2001. "Is SAARC a Viable Economic Block? Evidence from Gravity Model.” Journal of Asian Economics 12: 263-290.

Hausman, Jerry and William Taylor. 1981. "Panel Data and Unobservable Individual Effects." Econometrica 49(6): 1377-1398.

Koo, Won W., Lynn P. Kennedy, and Anatoliy Skripnitchenko. 2006. "Regional Preferential Trade Agreements: Trade Creation and Diversion Effects." Review of Agricultural Economics 28(3): 408-415.

Krueger, Anne O. 1997. "Free Trade Agreements versus Custom Unions.” Journal of Development Economics, 54: 169-187.

Levy, Philip I. 1997. "A Political-Economic Analysis of Free Trade Agreements.” American Economic Review 87(4): 506-519.

MacPhee, Craig R. and Wanasin Sattayanuwat. 2014. "Consequence of Regional Trade Agreement to Developing Countries." Journal of Economic Integration 29(1): 64-94.

Medvedev, Denis. 2010. "Preferential Trade Agreements and their Role in World Trade." Review of World Economics 146(2): 199-222

Oguledo, Victor I. and MacPhee, Craig R. 1994. "Gravity Model: A Reformulation and an Application to Discriminatory Trade Arrangements." Applied Economics 26: 107-120.

Romalis, John. 2007. "NAFTA's and CUSFTA's Impact on International Trade." Review of Economics and Statistics 89: 416-35.

Sohn, Chan-Hyun. 2005. Does the Gravity Model Explain South Korea's Trade Flows? The Japanese Economic Review 56(4): 417-430.

Susanto, Dwi, C. Parr Rosson III, and Flynn J. Adcock. 2007. "Trade Creation and Trade Diversion in the North American Free Trade Agreement: The Case of the Agricultural Sector." Journal of Agricultural and Applied Economics 39(1): 121-134.

Tang, Donny. 2003. "Economic Integration among the Asia-Pacific Economic Cooperation Countries: Linder Effect on Developed and Developing Countries (1985-1999)." International Trade Journal 17(1): 19-49.

Viner, Jacob. 1950. The Customs Union Issue. New York: Carnegie Endowment for International Peace. 


\section{ENDNOTES}

1 The complementarity index measures the extent to which the export structure of a country is complementary to its partner's import structure. A higher value of the index indicates a higher level of complementarity.

2 The authors' calculation from UN Comtrade Database. 